Yeshiva University, Cardozo School of Law

LARC @ Cardozo Law

2004

\title{
A Fragment on Cnutism with Brief Divagations on the Philosophy of the Near Miss
}

Peter Goodrich

Benjamin N. Cardozo School of Law, goodrich@yu.edu

Follow this and additional works at: https://larc.cardozo.yu.edu/faculty-articles

Part of the Law Commons

\section{Recommended Citation}

Peter Goodrich, A Fragment on Cnutism with Brief Divagations on the Philosophy of the Near Miss, 31 Journal of Law and Society 131 (2004).

Available at: https://larc.cardozo.yu.edu/faculty-articles/336

This Article is brought to you for free and open access by the Faculty at LARC @ Cardozo Law. It has been accepted for inclusion in Articles by an authorized administrator of LARC @ Cardozo Law. For more information, please contact larc@yu.edu. 


\title{
A Fragment on Cnutism with Brief Divagations on the Philosophy of the Near Miss
}

\author{
Peter GoOdrich*
}

This fragment is taken, mid-sentence as it were, from a longer discourse. It is plucked in process from a discussion of friendship for ideas. It is part of a longer journey through the annals of amity. The fragment also examines a fragment, a gloss on a text, a marginal comment, a handwritten note, which is taken to constitute the modern origin of Cnutism.

All of which makes me inordinately fond of the most nodal of spaces, that of the near miss. It is the zone of failures that come close to success, of successes that mingle, as they always must, with their own demise. It is the domain of the brief flaring or momentary venture in which we glimpse, but no more than glimpse, the recognizable presence of a friend. You know the sort of thing. The flush of fellow feeling, the sense of common critical apprehension, of shared insight, or elective affinity, and then it suddenly gets pulled up short. The friend votes with the opposition, or gets distracted and marries, or expresses affection for someone else, moves on, fails to write, or lets you down by posting someone else's letters rather than writing you their own. So let's think about these momentary relational modes, these fleeting flashes of amicable connection, these near misses.

The near miss implies both nearness and missing. Take your pick, but amity involves both. There is closeness and there is the lateral and often less visible sense of missing, of being to the side of where you wish to be. Friendship has always had a marginal site. In the French tradition, it has tended to be located in spaces that exist in between other things: the alcove, the ruelle or bedside, the dressing chamber, as well as the salon or chambre bleu, the blue room. We find it also in spaces of solitary connection. In the study, or the library or the laboratory, on a map, or inside an envelope, on a

\footnotetext{
* Cardozo School of Law, Yeshiva University, Brookdale Center, 55 Fifth Avenue, New York, NY 10003, United States of America

Many thanks to Lauren Berlant, Richard Collier, Drucilla Cornell, Marinos Diamantides, Peter Rush, and Pierre Schlag for offering comments and suggestions. An especial thanks to Ed Mussawir, for providing the Cnutist fragment. Thanks to Adam Gearey for suggesting publication. Especial thanks to Linda Mills for seeing it through.
} 
postcard, between the covers of a book. Or we encounter it more mundanely in cafes, bars, tea rooms, botanical gardens, chat rooms, restaurants, galleries, cinemas, and the like. Take these last and more normal examples. They are all transitional spaces, sites on the way to something, to eating, to seeing a movie, or to getting drunk, whatever that happens to mean to you. They are sites of passage both in the sense that there is something to be consumed and in the connotation of spaces of leisure.

If I am right - and who are you to think I am not? - then these variable architectural and scriptural spaces of amity place the friend by and large amongst beautiful or desirable things. Amongst things that we maybe love. Amongst relics, artworks, or culinary creations, or good wines. It is as if we imbibe friendship, through the mouth or through the eyes, but as a mechanism of risk avoidance we also tend to locate, and take it in with something else. The risks would otherwise be too great. That seems to be the case in all this embroidery and ornamentation of amity with leisure, with down time, with the ease of objects or images that can be consumed along with the friend. Perhaps it simply indicates that we want to eat the friend. Freud thought that, but whatever it is, it illustrates also that we cannot wholly have, or absorb, or ingest the friend. There is a degree to which we have to come close and miss. We have to mark our difference and in my case I need to tell the inside story.

Nietzsche described friendship through the metaphor of two ships in the night. The depressed Derrida talked about his 'all out friendship' for his dead friends. ${ }^{1}$ They both thought of friendship as a paradox, it was a sharing of solitude, it was the sighting of a face in the dark. It was a near miss. I agree but I want to give the near miss a more positive twist. It is our best, our all, our fate. Call it eloquence. I think of it as the moment of thought, the surprise of resistance. Like a caress that doesn't have to lead to anything more, like an intensely shared line from a poem or song, a frisson of recognition, a beautiful face glimpsed through a half open window, and then back to your meal or the movie or the next room in the gallery. A near miss is an intense hit. Excitations and animations all.

Here is a secret, though it won't be a secret for very long. Yesterday I received an email from a colleague in Australia. He attached a chapter from a doctoral thesis that he is supervising. It is an essay on my work. Early in the chapter, the author, one Ed Mussawir, and I like him a lot though I haven't met him yet, tells a story. Wittily discussing whether or not I have lived up to my name, he intersperses the following anecdote about me, or more specifically about the first book that I published:

1 The reference to 'all out friendship' comes in an encomium for Jean-Francois Lyotard, in J. Derrida, The Work of Mourning (2001) at 214-15. I discuss that and other instances in P. Goodrich, 'The Immense Rumor' (2004, forthcoming) Yale J. of Law and Humanities. 
It was not without a certain degree of irony for example that while reading Melbourne University's copy of Legal Discourse I discovered on page seventy eight the inscribed comment of an apparently frustrated reader: 'This book is written by a cunt of a bloke. Fucked if I can understand it!'2

Straight off, I have to admit that I have tended to have an ambivalent relation to commentaries and critiques of my work. I basically read them very inattentively. The critic has to work to get my attention. So, initially, my response is a little defensive. Sure, I marvel at how direct Australians can be, but then I find myself thinking something along the lines of:

\begin{abstract}
Hell, the book is the publication of my thesis and it was written for my examiners. One was bald and prone to wearing a kilt, a skirt, but he had a Latin title, Regius Professor, and was formidably well qualified and successfully learned in things that I did not dare even approach. And the other one still had hair, he is dead now, but his early books were so esoteric and incomprehensible that I could only pretend to have any idea of what he had written on. And I had no choice. I had to publish the book to get the job.
\end{abstract}

And that seems a pretty convincing answer to me. My antipodean tormentor would surely lay off if he knew all that. I am guessing it was a male. Kind of a stab in the dark, but it fits stylistically. I think one can say that it offers a male position and expression. Not so much a tone as a dose of testosterone.

I have to admit, however, that it is not that simple. I may have been scared and a little bit traumatized, but still I was doing the verbal equivalent of preening my feathers or polishing my armour or fixing the gaps in my chain mail. It may seem strange that my Australian glossator couldn't see that straightaway. And I could also point out that if this critic had actually written a thesis himself, he would also know that there is no way that one is going to rewrite it. Not for publication. Not for anything. Not after ten solid years before it finally got written and presented within a traumatic whisker of being out of time. And hey, I wrote that twenty years ago and since then I have changed. I am on to the next best thing.

Anyway, back to my being named after a colloquially invoked female body part. Thus, 'a cunt of a bloke' and then rapidly on to a post-coital state: 'Fucked if I can understand it'. Sit with the synecdoche, if you will, and then ride with the metalepsis. It is strong stuff. And, even if you are slow like me when it comes to facing my critics, it fairly soon occurs to you that this gloss on the text, the marginalia to page 78 , is pretty sexualized, and quite full of desire. I am not saying that it is in and of itself flattering, though one could say that, but more that it needs to be understood in terms of desire and frustration. Both poles are important. One is pushed towards viewing it as a critical case, and excuse the grammar but it is in the service of a bad pun, of lector interruptus. He really wanted to finish and it was most frustrating to pull up short and not

2 E. Mussawir, 'Portrait of a Legal Playwright: A Linguistics of Dramatisation' unpublished manuscript, 3. 
be able to do so. For him, it would seem to be a case, to coin a phrase, of bad textual intercourse. A near miss.

There is also the flip side. According to the usual modes of sentence construction, the two quoted clauses seem to imply that it is the author of the book who is invaginated, but it is the reader who is fucked. What kind of sense does that make? It is certainly messing with the usual stereotypes of sexual action and of textual function. It is also an earthy figure from a seeming literalist. I am even willing to imagine that he viewed the whole reading experience as an unwarranted tease, that he wanted more and got less. But for me, the passion is the thing. The steam in the stacks. The fact that the reader left a commentary. That the student became an author and let rip his feelings isn't nothing. To borrow a phrase from Pulp Fiction, the reader got medieval if not with my ass, at least with my text. That is undoubtedly something.

Well, I think I have probably said enough to convince you that despite my modesty I am in fact both attentive and responsive to my critics. Indeed I am not above changing my style, if I really have to. But that is a separate issue. I am on to a different question. I don't think my Australian glossator, the author of the interlinear interposition, really liked the book. I think it is safe to say that he didn't rush out of the library to buy a copy, although I hasten to add that he still could, I have quite a few copies left, and it can be purchased from Amazon.com in the United Kingdom, in case you are interested.

So the reader wrote me a letter. It took anything up to twenty years to arrive. It followed a very indirect path, but it is Slavoj Zizek's theory that the letter always arrives. In his rather morbid opinion the letter is like a bullet with your name on it. You can maybe postpone its arrival - by changing your address, by having it sent poste restante, by running, who knows - but in the end it is going to find its way to you. Apparently there is an epistolary equivalent of the maxim that you can run but you can't hide. That is just how it is, and in this case, and rather unusually in my opinion, S.Z. has a good point. Here I am, in fact discussing the marginal commentary and so I cannot avoid the conclusion that the letter arrived. Not only has the letter arrived, but on the surface at least it seems pretty critical, in fact rather negative.

Here is the thing. It arrived somewhat late in the day. It was a near miss. I had already changed my ways. I was already busy writing this. But it was a friendly act. A corrective correspondence. An honest expression, a heartfelt declaration of critical sentiments, a gloss in the margin of the law. I doubt that the author particularly cared if I saw it. But I also think that he would be happy to learn that I did. He would think it might help me shape up or write better. And if other students saw it, then they might be spared some frustration or released from their pain. No small thing, especially if you take into account the augmented suicide statistics for libraries. Okay, I made that last bit up, it is purely anecdotal, and just a figure of speech, a way of trying to keep your attention on my argument. Which goes as follows. 
The humanist legal tradition was all about the margins and the between the lines or interlinear spaces of the text. Lawyers were called glossators. They were trained to write in the margins and between the lines and at the top and the bottom of the page. And here, many centuries on, a student of law, though not necessarily a law student, glossed my text. It is powerful stuff, and if the punchy phrase sticks, that is also because we have already encountered the margin, the preface, the various thresholds and peripheries where affect and amity, emotion and enmity are invariably placed.

It is as simple as this. The margin is where the reader writes. The lateral and the interlinear are the nodal spaces in which the text encounters the living. They are the moments and the maps of law application. And here is precisely the space of amity and enmity, of correspondence, of handwritten familiar letters. This is the space where stuff gets done and it is truly sad and dysfunctional that we keep looking away. We ignore the marginalia and we overlook the near misses. And that way, truth to tell, unhappy to report, life passes us by or gets put in the hands of lawyers.

As a culture we tend to pay rather little attention to the peripherally visible. Frankly we are more likely to lock it up, or bomb the hell out of it, than pay attention, rest with it, and enter dialogue. And by that token, the near miss is a threat and a failure, an absence of presence soon likely to be turned to rubble. And then we have to add to that the curious yet real sense in which the metaphoric attribution of the characteristics of female genitalia is viewed as offensive or negative. I don't have to tell an auditor as sophisticated as you that the Latin for vagina means shame. But who reads Latin anymore? Could we not rather say that the genitalia are also erogenous and erotic, that sex is fun, and that if you got fucked by a book then talk to your therapist about your pattern of object choice. ${ }^{3}$

I confess that the last line is a bit too easy. In fact I think it is what we often do. We throw the criticism back, we get aggressive or dismissive, pompous, long-winded or sarcastic in the face of negative commentary. We are not comfortable with the difficult stuff that gets placed in the margins. We skitter at the sight of dirty words. We play like Teflon when reading criticisms of our work. We just don't like it. It is not amicable in the easy and fatuous sense in which we think of working amity and tend to define it as an invisibly tight bond of repetitive affirmation, or as the reoccurrence of the self in someone else.

Back fleetingly and perhaps finally to the critical marginalia and to my interpretation of it. This may come as a surprise. It was a surprise to me and I

3 Just as an aside, the analysis could get pretty complicated. Imagine how it would go: 'my lover is a Lacanian and so he refuses to say his own name'; 'she follows Zizek and only ever allows me to look at her genitalia'; 'I know he is besotted with Irigaray but please help us through the differences'; 'he has been reading Judith Butler and now he is convinced that he has to fake all his orgasms'; 'he is a deconstructionist and so whenever we arrange to meet it is never in the same place'; 'he's an old fashioned Sartrean and only loves me for what I am not'; 'she's a Levinasian and will only make love to my face'. 
think its pretty good. My intermediary, Ed Mussawir, has this to say of Goodrich the name, because he has never met me: 'But having been called a "cunt of a bloke", I dare say, he may never be the same again ...' 4 And that is the point. The criticism matters. Even if I hadn't read it at that point in time when it was sent, I was changed already, in anticipation, by prolepsis.

The correspondence was sent to me. The letter arrived and I read it. And it did cause me thought, engaged me in dialogue, put me in touch with a different reading and view. I am even willing to go a bit further. I think that the marginal, and here I fear sounding too like the literary critics, is key. It is just a fragment but it got through. It was hard on me but that is precisely the space of dialogue, of amity and enmity. And I can offer one further example, another interpretation of it as a near miss.

Looking back it was a difficult text. I had been under the impression, you will recall, that I needed a lot of fancy theory to get by my examiners. It worked. I looked all scientific and serious. When I met people for the first time they expected someone with a pipe, gray hair, a tweed jacket, and roughly eighty years old, back hunched from all the texts that he was carrying inside. And I was able to shock them, look at the picture, long thinning black hair, fine aquiline nose, impertinent eyes, and youthful gait. A near miss between the name and its current incumbent, between the text and the bloke who wrote it.

Yet that is not in the end my point. There is another near miss, a mix up of the middle two letters in the word cunt. I don't think the critic necessarily meant what we on the East coast would mean by cunt. I think there was a transposition of the $\mathrm{n}$ and the $\mathrm{u}$. Quite understandable. Easily done. Happens a lot. It is the figure of synchisis or confusion of letters. And, of course, the $u$ is an $n$ upside down. All of which is to say that the word that fit was Cnut. A Cnut of a bloke, meaning a fossil, an archaism, and the equivalent of King Cnut. It is pronounced Canute but spelled Cnut. He was the Anglo-Saxon King, you will undoubtedly recall, who got so fed up with the sycophancy of his courtiers that he decided to prove to them that he was not a God. He devised a radical demonstration of his all too human frailty. He was carried on his throne to the sea at low tide. There on the edge of the incoming water, he regally ordered the tide to stop but the sea came on in anyway.

King Cnut was trying to prove something or other to his followers. As I said, I think the point of the myth and of the scenic ritual was to show the limits of sovereignty and the absurdity of worshiping the King. If that was the purpose then you might think he would have made the point better if he had walked to the sea but we have to allow for the paradoxes. After all he was King, and being human is not a disqualification for sovereignty even today. He wanted to share the fact that he had his failings, his flaws, his near misses. Like, for instance, he couldn't stop the tide.

4 Mussawir, op. cit., n. 2, p. 8. 
Me neither. Though it was not the sea but rather the law that I was ordering to stop, ex cathedra, with all my Latinate words. And so my interpretation of a Cnut of a bloke, of a Cnutist, is someone who is addicted to the positivity of failure or, put it like this and in the positive, to the semiotic significance of the impossible. In that form it is a pretty witty apothegm and not without its accuracy. After all, what was Legal Discourse the book? It was the work of a left-leaning, rather shy, English doctoral student that offered a theory of legal language as the prosaic equivalent of a dominatrix. Aged twenty-three, and with rather less sexual experience than your average second millennium mid-teen, he was arguing for the radical dismemberment of law. And why not stop the tide coming in as well? So what do you think? A touch of Cnutism? I guess so.

Don't worry. I am not planning on starting a school or a movement. Nothing like that, though 'the Cnutists' does sound fun and kind of risky. Just a transposed letter away from a reference to what Leonard Cohen calls a highly prized five inches of flesh. It is also just a $c$ ahead of a nut. But let's just say that Cnutism describes me back then, and a lot of my colleagues now, pretty well. And on top of that, it just remains to say that I will leave it to others, to Kim or Pierre, Patricia or Jack, or just possibly D.K. and Professor D. to point all that out to the lumpen professoriat.

So, talking of near misses, Cnutism captures the narrow window of the near miss quite excellently. It also, incidentally, proves that there is no phrase nor turn of words that cannot be improved upon with a little serious interpretation. But first off, I want to acknowledge that I owe my sense of the concept or rite of Cnutism to my critic, and to a productive misreading of a seemingly acerbic fragment meant at least in part for me. So let me just note that the concept of the near miss derives from an interruption and expresses that interruption. It refers to a break in the pattern, a missed beat, a gloss to the side of the text.

Next, I need to point out that the Cnutist makes a virtue of failure. Cnut turned his impotence into a powerful lesson. There is an exquisite closeness and a didactic miss. And part of the lesson was obviously that failure is something to learn from and specifically that we need to recognize who we are. There are a lot of things, sovereign or subject, Cnutist or Marxist, liberal or feminist, that we just cannot do. Sooner or later you are going to have to face up to your near misses. And perhaps surprisingly given how little account history has paid to Cnutism, it turns out to be quite an optimistic enterprise.

Suddenly you can examine your apparent failures in the light of the successes that can be derived from them. You can look at failure as part of a bigger picture. Think of it like this, or maybe just think of what happened to Cnut. He didn't just float off, though he could have. The tide came in and his suite or following or courtiers or whoever rescued him and carried him out of harm's way. So he lived to prove his lesson and maybe the courtiers got a 
little bit more real about who he .was. More than that, had everyone waited long enough, had they been as patient as they should have been, then the tide would eventually have gone back out. Come dusk, and Cnut's order would actually have been repaid in spades: the tide would not just have stopped, it would have receded. He would by that point in time have been waving to the withdrawing waters over the dusky horizon. Which is quite a thought. Actually, I like to think of that moment as a Cnutist triumph though it is also possible that he had misread the tidal schedule.

And then, of course, rapidly on its heels, the tide would be up again. That is just how things are. But it does bear pointing out that when the tide comes in again, Cnut would be proving his hypothesis. So in the longer term, he would be right both ways. That is what my therapist would probably call the bigger picture. The long term perspective on tidal flow. The deeper point, however, or more accurately the temporally enlarged point is that none of the above depends in any way upon Cnut's proclamation. His law, because what the sovereign says is in fact the definition of law (ask Austin if you have any doubts on that), has nothing to do with what happens. Or rather it has few direct effects, many near misses.

Another way of saying the same thing, would be that my book Legal Discourse had absolutely no direct impact upon the making of law. In a way we know that already. As an innominate Australian critic put it, the book was written by a Cnut of a bloke. And as he also pointed out, it wasn't that easy to understand. Nor, to be absolutely honest, would I ever have expected it to have persuaded lawyers or lawmakers. Back then in fact we were busy planning on overthrowing the lawyers, toppling the law, as it were, and at the very least, if revolution wasn't on the cards, we were going to ignore the law. That would show the ruling class what was what. And that kind of an attitude doesn't usually lead to a constructive conversation although my leftist peers seemed happy enough that we were talking amongst ourselves.

Returning to me, which after all is my fate, and I can't in the end help it, I wouldn't be looking for the practical impact of a theoretical treatise, written as a doctoral thesis in philosophy of law, such as Legal Discourse. Funnily, though this helps explain the Australian critic's frustration, the book was used on a number of courses in legal theory and in socio-linguistics. It sold quite well. Got reprinted a couple of times. And if I wanted to assess its impact, I would look to the margins. I would try to find out whom it upset as much as whom it pleased. I would ask about conversations, as well as citations and quotations and all those more frontal but less significant accolades and apprehensions. I would try to find out what happened in the alcoves, what got said under the stairs, in the corridor, to the side of the hallway, or behind closed office doors. Indeed that is the thing with us Cnutists. We look to the long term. We read footnotes. We are happy to wait. We don't need to be that important. Which is lucky, actually, because in fact we are not very important, not that significant at all except that we realize it and are willing to display our unimportance through curious but occasionally memorable feet wetting rites. 
Staying with continents beginning with the letter A, here is another story. There is a judge on the High Court in Cape Town who also teaches at the Law School there. He teaches Legal Discourse, as it happens, and he says that the students find it pretty hard going but he persists. I am not sure why. Can't remember. I don't listen that well to that sort of conversation, but I do seem to recollect that he had a reason. Maybe he thought I was right. After all, it is not impossible and he was a leftist. Still is, so he claims. In any event, I am arguing that to understand what happens we need to look to the margins, the near misses, the influence and animus of friends.

So he told me that he was sitting on a case brought under the new South African Constitutional provision guaranteeing economic rights, including housing. The case was being heard shortly before the end of term and the beginning of the Christmas vacation. A group of women and children came to Court and tearfully argued, through their representatives, that the new Constitution required the state to house them. And otherwise they would all be sleeping rough over the holidays. Which is not a bad argument, rhetorically speaking.

My friend, let's say Judge Dennis D., who told this story quite openly at a conference I attended, wanted to be able to interpret the Constitution to require the state to provide housing. But he knew that if he couldn't persuade the senior judge then it wasn't going to happen. Try as he might, the senior judge just wasn't buying it. Prospects were bleak until the end-of-term office party or whatever the High Court equivalent happens to be. At the party, Judge Dennis D. happened upon the senior judge's wife. He told her about the case, and about the women and the children who might be living outside over the holidays. The weather forecast wasn't good. That sort of thing, and he must have been pretty eloquent, and she must have been quite moved. I say that because the next day, according to Judge Dennis D., the senior judge came in and said something like 'it is time to settle this, I am going to vote with you'.

From a Cnutist perspective, that is another margin accessed and analysed. That is how it goes. Those are the lines of power, the incidents of amity, even amongst those who are not the best of friends. Put it like this, it was a near miss but it worked out quite well. He couldn't persuade the senior judge but he managed to persuade his best friend, the queen of his friends according to the old Christian manuals on amity, his wife. And that did the trick. If you cannot persuade the judge, persuade a friend of theirs, or in Platonic terms, persuade them through ideas with which you know them to be friendly. Your near misses, or indeed your talk with the misses, may end up getting the job done.

I could lard all of this with a bit more theory. I could cite the very chipper Kipnis on marital confinement and the erotics of office amity. Or I could dazzle you with quotations on desire and lack, love and impossibility from Jacques Lacan. I find him pretty funny, but come to think of it he probably actually was a cunt of a bloke. That is going by the sounds of it, in that his 
daughters' books on their father aren't too flattering at all. Or there is always Zizek, S.Z. as I think of him, on cultural trends in waxing pubic hair, the trajectory from the bikini line to the Brazilian. But it would be just so much additional lard. We Cnutists are far more into the practicalities.

The philosophy of the near miss simply poses an old fashioned question in a twisted yet optimistic way. So here is the thesis. Essential, I would say, but placed in the margins, there are feelings of amity and enmity that basically determine what gets done. It is here, in the epistemic alcove that the manipulations of reason and the armature of slogan and spin get set up. It is the zone of near misses, because close and warm though the margin may be, these amicable and animated affects don't make it into the text. That is a start, but there is more to it.

The philosophy of the near miss is an attempt to capture the ambience of our times. Let's say that the times they are a-rolling. I don't simply mean that obesity is on the up, though it is. I am thinking also of near misses, the fads, the trends, and the paranoia. Postmodernism came and went by the turn of the century. Y2K, the millennial computer virus never took. Didn't bite. The love bug e-mail of May 2000 caught the business world with its pants down, but what's a few billion dollars here or there? The 'sobig' email worm, like most such size-based claims, proved to be an exaggeration. Feminism is finally fading, and the political scene is frighteningly retro. So there is a contemporary catalogue of near misses. Nothing new in that. You can figure out your own list. From bull to bear you have got to admit that the near miss captures that sense in which nothing is entirely certain. We come close but we neither control, nor possess, nor fully consume the local events that make up our lives. It is time to turn our attention to them. They are the anthropological key.

Here goes: physical anthropology has long observed that like other species, when humans feel strongly about each other they will literally put their heads together. Think of Don Zimmer screaming at Pedro Martinez. ${ }^{5}$ He was right in his face. And if you are falling in love or having an office affair or you are simply French it won't be long before one or other of you says 'shut up and kiss me'. You will go head to head. You will touch, taste, smell the other head. But you won't be able to get inside. The analytic philosophers, not that I care about what they have to say, used to talk of this in terms of the problem of the other mind. Fair enough, though I would prefer the possibilities of the other mind. In either event, you cannot be the person you love. You cannot erase the person you hate, at least not without facing the danger of immortalizing him. And you wouldn't want that.

5 There are some who would probably say that sports metaphors don't help. In fact I am not sure if either of the names is correct. So you can change them as you wish. It could be Bill O'Reilly shouting, spinning out of control, thug that he is, with Barney Frank. Or Dick Cheney finally getting to meet Al Franken, or Bill Clinton and Ken Starr on the same page. Kitty Mackinnon debating Camille Paglia is another possible. Or go with a great love. Clark Kent and Lois Lane. Jason the Argonaut and the Sirens. Whoever. We are talking a whole load of near misses. 
We cannot wholly know, or feel, or be the other person. That is how it is. We can get close. We can even be marginally inside each other and as a best possible outcome we can share what Nabokov termed a 'little death'. But there is still the barrier of the body, the weight of the unconscious, the fact that as often as not we are living out the philosophy of the near miss. It is a matter of the pragmatics of Cnutism. I will put it like this, a radical formulation, the maxim of the near miss: there are feelings that just don't have an epistemic equivalent.

Like all good maxims, that one is a little opaque. But I don't want to be upsetting my Australian reader; I can take a hint in the margins as well as the next Brit, and so I will try to translate. I think it means that we get ahead of ourselves. When things get hot and heavy, when we light up or burn away, we are way in front of our rational selves. We are making out or letting go. It is what tennis players call being in the zone. It is a great feeling, it's super cool, and it doesn't last. But us Cnutists, we like to think that it is important. We think that what happens matters.

When you go head to head, when you want to be inside the other person, to convert them or to love them, there comes a point when you realize, friend or enemy, that it's not going through. It is the moment of the Lysis, of the untangling, of sitting back in pleasure or pain, doesn't matter, and apprehending that this is all there is: a painful proximity, an exquisite flush, a near miss, that comes along with passing through. 